\title{
Mirante da cidade e o tempo que reluz: rememorações na obra Os canhões do silêncio, de José Chagas
}

\author{
Ernane de Jesus Pacheco Araujo* \\ Silvana Maria Pantoja dos Santos**
}

\begin{abstract}
Resumo
A obra Os canhões do silêncio (2002) do poeta naturalizado maranhense José Chagas tem como espaço de rememoração o mirante: construção elevada dos casarões coloniais que ambienta os centros históricos, nesse particular, o da cidade de São Luís, do Maranhão. Esta estrutura erige-se como um monumento edificado entre passado/presente, sendo visto na poética de Chagas como um local de acolhimento do tempo, onde se reconstrói e reconfigura memórias. Nesta construção arquitetônica, lugar do dizer poético, espaço e tempo se fundem, convertendo-se em uma unidade indissociável que se dilui na subjetividade do eu lírico. As imagens do passado, reconfiguradas poeticamente, testemunham memórias no (des)contínuo processo de ser e estar no mudo.
\end{abstract}

Palavras-chave: Cidade. Tempo. Mirante. José Chagas.

\section{El mirador de la ciudad y el tiempo que reluce: rememoraciones en la obra Os canhões do silêncio, de José Chagas}

\begin{abstract}
Resumen
La obra Os canhões do silêncio (2002) del poeta naturalizado maranhense José Chagas tiene como espacio de rememoración el mirador: construcción elevada de los caserones coloniales que ambienta los centros históricos, en particular, él de la ciudad de São Luís do Maranhão. Esta estructura se erige como un monumento edificado entre pasado/presente, siendo visto en la poética de Chagas como un local de acogida del tiempo, donde se reconstruye y reconfigura memorias. En esta construcción arquitectónica, lugar del decir poético, espacio y tiempo se funden, convirtiéndose en una unidad indisociable que se diluye en la subjetividad del yo lírico. Las imágenes del pasado, reconfiguradas poéticamente, atestiguan memorias en el (des)continuo proceso de ser y estar en el mundo.

Palabras clave: Ciudad. Tiempo. Mirador. José Chagas.
\end{abstract}

Recebido: $18 / 03 / 2018$

Aceito: $26 / 09 / 2018$

\footnotetext{
* Mestre em Letras/Teoria Literária pela Universidade Estadual do Maranhão - UEMA. Professor do Instituto Federal do Maranhão (IFMA/Campus Barreirinhas) e da Rede Estadual do Maranhão (SEDUC-MA).

** Doutora em Letras/Teoria Literária. Professora de Literaturas de Língua Portuguesa da Universidade Estadual do Maranhão - UEMA e da Universidade Estadual do Piauí - UESPI. Professora do Mestrado Acadêmico em Letras das referidas universidades.
} 


\section{Introdução}

A representação da cidade na literatura depende do modo como o escritor faz uso dos espaços e de seus elementos concretos e simbólicos. A urbe, enquanto um texto a ser decifrado, permite a apreensão de significados mediante a leitura/uso, sendo o próprio uso passível de leitura. Os signos citadinos são uma via de representação simbólica pautados em sociabilidades capazes de pôr em cena experiências individuais e interpessoais. Assim, o registro literário decorre da leitura dos espaços e de formas urbanas, cujas singularidades dão testemunho de acontecimentos que perpetuam no imaginário social. Aquilo que está sob o texto-cidade desnuda aspectos históricos, culturais, bem como sensações que emanam de seus espaços de vivências.

Ante o exposto, propõe-se analisar as interfaces entre tempo e cidade na obra Os canhões do silêncio, de José Chagas, tendo o mirante como lugar de memória, onde passado e presente se cruzam e dialogam, construindo percepções sobre o espaço. Esta produção poética, publicada em 2002, constitui-se de um longo poema composto por 284 páginas.

José Chagas, poeta naturalizado maranhense, foi membro da Academia Maranhense de Letras (AML), ocupando a cadeira de número 28. Foi considerado, ainda em vida, um monumento vivo da cultura local. Escreveu mais de 20 obras poéticas, dentre as quais se destacam: Canção da Expectativa(1955) - livro de estreia, Maré Memória (1973), Lavoura Azul (1974), Os telhados(1999), De Lavra e de Palavra (2002) e Os canhões do silêncio (2002).

Os mirantes são espaços de construções arquitetônicas localizadas acima dos telhados de casarões antigos que remontam ao Período Colonial. Outrora, eles tinham várias funções: serviam de observatório da chegada dos navios carregados de especiarias; quartos de hóspedes; locais reservados para segregar os doentes e os loucos ou para guardar móveis velhos.

Os mirantes eram também lugares de isolamento, apropriados para refletir e escrever: o poeta maranhense Graça Aranha escreveu a peça "Malazarte" recolhido em um mirante. O poeta piauiense Hindemburgo Dobal Teixeira, conhecido no meio artístico-cultural como H. Dobal, da clausura de um deles, buscou inspiração para a feitura da obra "A cidade substituída". "E no mirante, um gentilhomem/sossegado entre o céu e a terra,/ velando a vida e a tarde branca/ escolhia palavras para um livro" (DOBAL, 2005, p. 185). Para além do sentido literal, o espaço carrega simbologias. Santos $(2015$, p. 240) assevera que "o mirante erige-se como um monumento ou uma torre, divindade gloriosa que irradia eternidade ante o efêmero".

Figura 1: Mirante de um casarão de São Luís

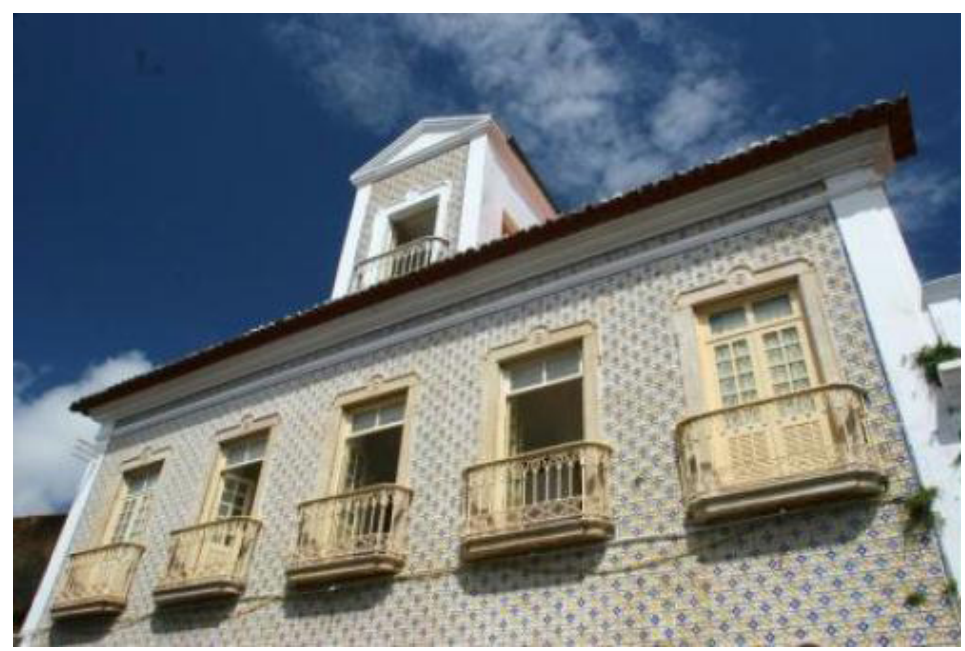

Fonte: http://ohturismonobrasil.blogspot.com.br/2011_02_01_archive.html 


\section{0 mirante e o tempo}

Em Os canhões do silêncio (2002), o mirante comporta um tempo que não transcorre, de modo que a percepção do sujeito poético passa a ter fundamental importância. De acordo com Bergson (1999), a matéria age sobre o indivíduo e atua como estímulo que instiga a percepção, isso porque entre estímulo e resposta há uma imagem privilegiada que é o corpo.

Há um sistema de imagens que chamo minha percepção do universo, e que se conturba de alto a baixo por leves variações de uma certa imagem privilegiada, meu corpo. Esta imagem ocupa o centro; sobre ela regulam-se todas as outras; a cada um de seus movimentos tudo muda, como se girássemos um caleidoscópio (BERGSON, 1999, p.20).

O corpo é definido como uma imagem privilegiada, posto que é o centro a partir do qual todas as outras imagens se movimentam. Enquanto centro, ele as seleciona dentro de um universo que o circunda e tudo muda a cada novo movimento.

Bergson (1999) acrescenta que não há percepção sem que esteja impregnada de lembranças. Os dados atuais se misturam a experiências passadas, assim a memória desloca a percepção sobre as coisas. No imbricamento entre presente e passado, surgem várias ilusões de realidade. As lembranças não são fixas como se depositadas na memória, mas sim reconstruídas. Nesse sentido, vale dizer que Os canhões do silêncio constitui-se como depositório de imagens capturadas pelas retinas do sujeito poético. A obra se inicia como a seguinte estrofe:

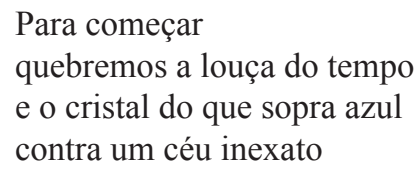

(CHAGAS, 2002, p. 39)

O eu lírico principia a construção poética dizendo que a "louça do tempo" deve ser quebrada. Dessa maneira, coloca em questão o tempo objetivo, o qual se instaura como absoluto. É Cronos (Kpóvos) que a tudo devora, sendo senhor soberano do homem. No entanto há um outro tempo o qual flui no interior do ser, o subjetivo: das recordações, dos sonhos, dos desejos e das vontades.

Desse modo, a "louça do tempo" deve ser quebrada, a fim de que se adentre no tempo subjetivo, também do fluxo da consciência, da zona de indeterminação do sujeito. Acerca dessa temporalidade, o eu lírico anuncia: "Me alimento de tempo/e duro horas inteiras de sonho" (CHAGAS, 2002, p. 59).

O eu poemático não se assujeita ao absolutismo da cronologia cartesiana, antes, constrói sua própria lógica, atemporal, psicológica, interior, em que se demora, perde a progressividade, a velocidade e caminha ao encontro de si mesmo.

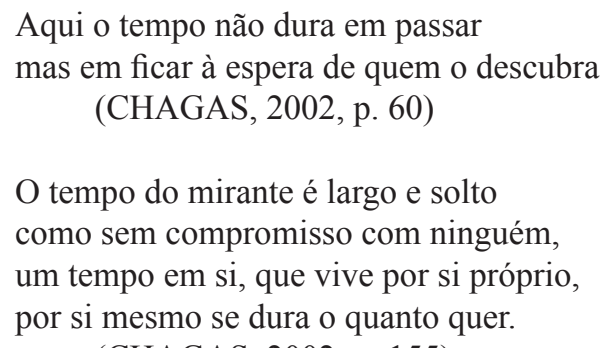

O mirante, então, é tido como um lugar em que a lembrança tem repouso absoluto. Enquanto construção arquitetônica está sujeito à ação do tempo objetivo, mas enquanto espaço do dizer poético é uma zona de devaneio, de rememoração. Neste sentido, quebra "a louça do tempo", desmaterializa a construção arquitetônica e funda-se na subjetividade, em que se encontra o "tempo em si, que vive por si próprio". 


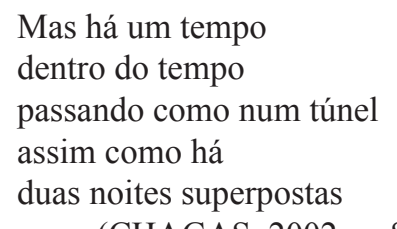

(CHAGAS, 2002, p. 87)

Tem-se, com isso, um tempo que se manifesta na materialidade da vida; outro que se insere nas memórias e percepções. A temporalidade cartesiana, presente na dinâmica da vida, estimula memórias de passados vivenciados. Por sua vez, o contexto das recordações interfere na forma como o sujeito interpreta a realidade objetiva.

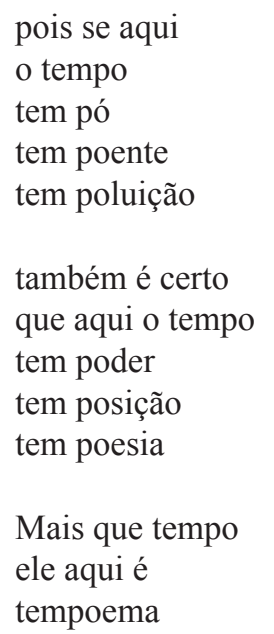

(CHAGAS, 2002, p. 87)

O tempo do "pó", do "poente" e da "poluição" coabita com o do "poder", da "posição" e da "poesia"; o da materialidade e da mentalidade das coisas e do sujeito, da vida e da existência implicamse mutuamente, criando teias semânticas, sinápses de significação e ressignificação. Não há oposição entre os elementos que identificam ambos, ao contrário, há complementariedade como evidencia a estrutura linguístico-poética: "pois se aqui/ o tempo/ tem [...] também é certo/ que aqui o tempo/ tem”, referindo-se as duas temporalidades. Desse modo, pode-se dizer que em "tempoema" coexistem o tempo objetivo e o subjetivo, os quais se cruzam, imbricam-se e relacionam-se, construindo teias de sentidos no poema.

\section{0 mirante: lugar do dizer poético}

A cidade/texto dá vasão ao mirante, lugar do dizer poético. O eu lírico desmaterializa-o enquanto construção em pedra e cal e o coloca no plano do tempo subjetivo. Desconstrói o espaço físico e seu caráter pragmático, deslocando-o do plano material para o imaterial, lugar de memória, sonho e poesia.

Este é o mirante

da vida inteira:

guarda bastante

sonho e poeira,

guarda a estrutura

do quanto em pó

sustenta e apura

solidão só, 
guarda uma história

que sem ter fim

é transitória

no mundo e em mim,

(CHAGAS, 2002, p. 48-49)

O eu lírico diz que o mirante "guarda bastante/ sonho e poeira". Ao falar de "poeira", refere-se ao seu caráter material enquanto estrutura física, que com o passar do tempo tende a se deteriorar. Bachelard (2008) comenta que dar espaço poético a um objeto é dar-lhe mais espaço do que aquele que ele tem objetivamente, ou, melhor, é seguir a expansão de seu espaço íntimo.

Em Os canhões do silêncio, a espacialidade do mirante se expande e ultrapassa as paredes de pedra e cal, direcionando-se para o mundo da imaginação e da rememoração, onde o sujeito pode encontrarse consigo mesmo, penetrando na intimidade do ser, em que estão a lembrança e o esquecimento, duas faces da mesma moeda, que revelam e escondem aquilo que o ser é na sua interioridade.

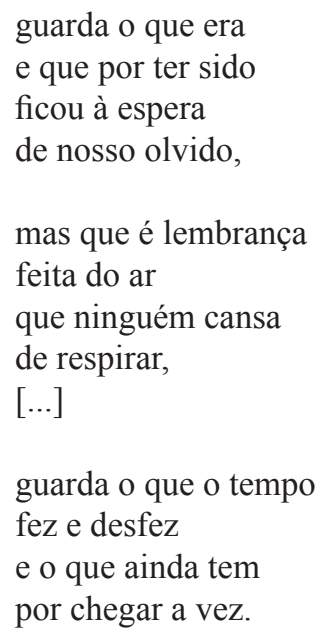

Heidegger (2003, p.169) fala que "o tempo encaminha o que a simultaneidade entreabre: o tempo-espaço [...]. O mesmo deve-se dizer do espaço, que entreabre, libera e concede localidades e lugares, assumindo o simultâneo como espaço-tempo". No mirante, espaço e tempo tornam-se uno, indissociáveis. "O tempo se torna espaço/que se fecha no mirante." (CHAGAS, 2002, p. 51). $\mathrm{O}$ espaço guarda o tempo dos antepassados. Cada marca, raladura ou arranhão são linguagens que comunicam vivências. E, mais ainda, o mirante torna-se uma unidade com o eu lírico:

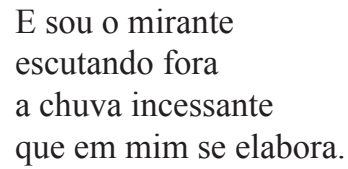

(CHAGAS, 2002, p. 152)

O mirante aqui se metamorfoseia, passa a ser todo sensações. Forma-se, desse modo, uma tríade sujeito - mirante (lugar) - tempo. O tempo subjetivo confunde-se com o espaço, que se dilui no sujeito, de modo que este não diz mais "eu sou o que sou", mas "eu sou onde estou", tal como diz Bachelard (2008, p. 287), citando um verso do livro L'État d”'Êbauche (Estado do Esboço): “Sou o espaço onde estou".

\author{
Vivo o espaço \\ que a vida oferta \\ no quanto passo \\ da porta aberta. \\ Porque sou fora do tempo
}


e minha vida tem o tamanho

do espaço que me ocupa

Vivo o onde

não o agora

(CHAGAS, 2002, p. 68)

O mirante é o lugar poético, a partir do qual o sujeito enuncia sua fala, reconstruindo-se dentro do tempo subjetivo. E como se configura o sujeito que fala? Centralizado, dialógico ou deslocado (fragmentado)?

Quantas vezes me achei antes, quantas vezes me achei depois mas nunca no instante certo de estar comigo para o ajuste pessoal de mim com o que sou (CHAGAS, 2002, p. 146)

Assim, o homem vazio do que foi e do que é, não acha a ponta do fio de seu novelo de fé.

(CHAGAS, 2002, p. 239)

O vento sopra a minha alma que para longe flutua e some na noite incalma como poeira de rua. (CHAGAS, 2002, p. 273)

O eu poético de Os canhões do silêncio é inquieto e movente. É o vazio que o movimenta. É um ser em constante procura. Um eu diluído no tempo e no espaço, que segue o fluxo da vida, sempre cambiante, flutuante como o vento, fluido como a água e os gases.

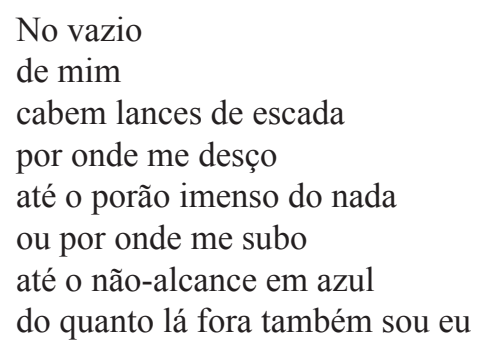

O vazio é o princípio de tudo, o marco zero, é o início da criação. No vazio do eu lírico cabem "lances de escada" que se direcionam do "porão imenso do nada" até "o não alcance em azul", dependendo do sentido do movimento: descida ou subida. O mirante é este lugar vazio o qual se dilui no sujeito. O nada é a ausência de existência, a negatividade do ser, mas também é o que garante a existência porque o ser "é" em virtude de não ser o "nada". Ser e Nada se complementam. O nada, para o eu lírico, está abaixo do vazio, em um "porão" e acima dele está aquilo que denomina de "o não alcance em azul", o que está para fora da janela do mirante, a amplidão da cidade, o céu, a infinitude cósmica. O sujeito poético localiza-se na unidade tempo-espaço, sendo oscilante, cambiante, mutável, deslocando-se a partir do vazio, ora para o Nada ora para o Ser. 


\section{0 mirante e as memórias da infância e do bairro do Desterro}

Em Os canhões do silêncio a memória está presente e atuante, permitindo a reconstrução de várias imagens, uma delas são as lembranças da infância e do Desterro, bairro situado no Centro Histórico da cidade de São Luís, No poema a seguir, o sujeito poético relembra o contexto da infância em que "soltava papagaio" (pipa), brincadeira geradora de sensação de liberdade que não era plena, pois o papagaio estava preso a uma linha por onde o menino controlava o seu movimento. Assim, o brinquedo constitui um elemento simbólico que distancia e aproxima do seu outro eu - menino.

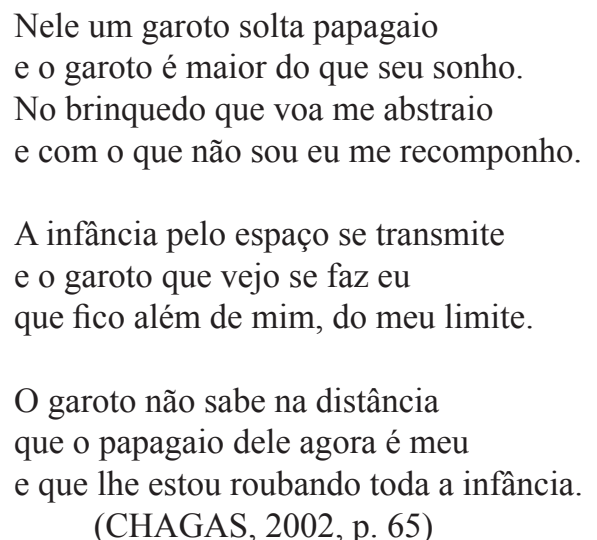

Nessa lembrança, há a presença do mito do eterno retorno, o mergulho na subjetividade, a volta ao passado para atualizá-lo no presente, por isso diz "No brinquedo que voa me abstrai / e com o que não sou eu me recomponho". Neste contexto, passado e presente se cruzam, gerando um momento único na memória do menino-homem: a infância, descrita como o tempo da inocência, cujo retorno é inviável.

Como diz Benjamin (1987, p. 224), "a verdadeira imagem do passado perpassa, veloz. O passado só se deixa fixar como imagem que relampeja irreversivelmente, no momento em que é reconhecido". O passado é uma representação imagética de um acontecimento e toda rememoração é uma reconstrução subjetiva do vivido. "Articular historicamente o passado não significa conhecê-lo "como ele de fato foi. Significa apropriar-se de uma reminiscência, tal como ela relampeja num momento de um perigo" (BENJAMIN, 1987, p. 224).

O porão é um lugar de despejo das inutilidades ou de coisas que não se quer ou não se pode desfazer. Nesse local sombrio, misterioso e vazio, símbolo do inconsciente na perspectiva bachelardiana, está o brinquedo, revisitado pelo eu poemático, mas que lhe escapa, porque o inconsciente não obedece à vontade. Compreendendo isso, o eu lírico tenta reconstruir seu brinquedo de menino-adulto, ressignificando aquilo que pode ser revisitado pela consciência:

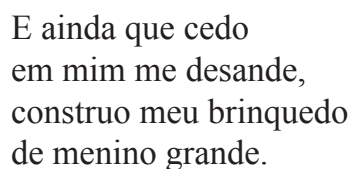

(CHAGAS, 2002, p. 67)

O eu lírico fala, ainda, sobre as memórias da infância que lhe causam solidão e saudade, retomadas a partir da janela. Santos (2015) assevera que as janelas, assim como os binóculos, têm a função de enquadrar as cenas, de modo a impedir o transbordamento da visão periférica. 


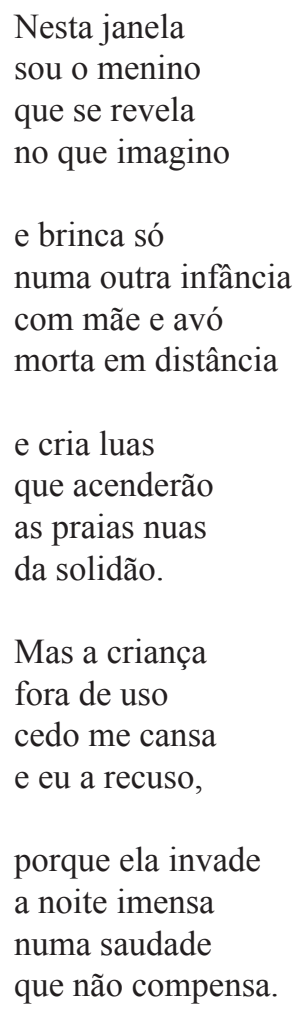

(CHAGAS, 2002, p. 93)

A janela do mirante se abre para o tempo subjetivo, o tempo das lembranças. O sujeito lírico diz "Nesta janela/ sou o menino". Localizadas na infância, as memórias vão surgindo: recorda-se da mãe e da avó "morta em distância", símbolos da origem, da criação, força matriz, geradora, Gaia. Bachelard (1988, p. 120, grifos nossos) diz:

\begin{abstract}
A lembrança só faz reabrir a porta do sonho. O arquétipo está ali, imutável, imóvel sob a memória, imóvel sob os sonhos. E, quando se faz reviver, pelos sonhos, o poder de arquétipo da infância, todos os grandes arquétipos das potências paternas, das potências maternas retomam a sua ação. O pai está ali, também ele, imóvel. A mãe está ali, também ela, imóvel. Ambos escapam ao tempo. Ambos vivem conosco num outro tempo. E tudo muda: o fogo de outrora é outro fogo, diverso do fogo de hoje. Tudo o que acolhe a infância tem uma virtude de origem. E os arquétipos permanecerão sempre como origens de imagens poderosas
\end{abstract}

As lembranças da infância revelam muito sobre o ser. São memórias que perduram no tempo e estão ligadas a um valor afetivo. São recordações relacionadas ao sentimento do sujeito, as quais possibilitam compreender seu estado, suas emoções e suas sensações.

Do mirante, o sujeito poético constrói memórias do Bairro do Desterro (um dos mais antigos logradouros de São Luís), que recebeu esse nome em função da Igreja de Nossa Senhora do Desterro, a qual foi destruída pelos holandeses em 1641. Foi reconstruída em 1832 por devotos de São José, liderados por José Lé, negro convertido ao catolicismo, passando a denominar-se Igreja São José do Desterro, constituindo-se a mais antiga de São Luís.

O Desterro é um velho bairro que fica para o lado do tempo situado entre a fé e o vício lá onde moram sombras pagando aluguel de medo e onde o tempo despeja a massa de seus dias para montar sua usina de memórias eternas

(CHAGAS, 2002, p. 203) 
No poema, o eu lírico localiza o bairro dizendo "que fica para o lado do tempo". O bairro passou por várias transformações e foi palco de muitos acontecimentos, tal como a guerra entre portugueses católicos e holandeses protestantes no processo de expansão marítima, territorial e comercial, que resultou na destruição da Igreja do Desterro e na profanação da imagem de Nossa Senhora, quebrada pelos holandeses, vitoriosos na batalha. Assim, o eu poético monta a "sua usina/de memórias eternas", recuperando subjetivamente o tempo histórico.

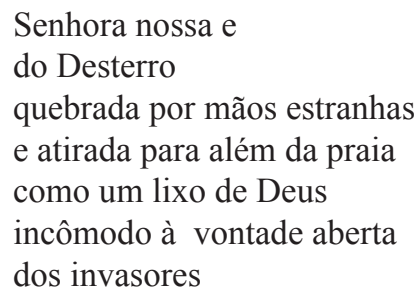

Ao referir-se aos holandeses, o eu poético chama-os de "mãos estranhas" em virtude de possuírem identidade, discursos e práticas diferentes, conflituosas e opostas a sua. Sobre o processo de reconstrução da igreja, o sujeito lírico ressignifica a história, sem se aprisionar à factualidade, antes, usa elementos metafóricos e imagens contraditórias que se fundem e produzem sentidos distintos do histórico.

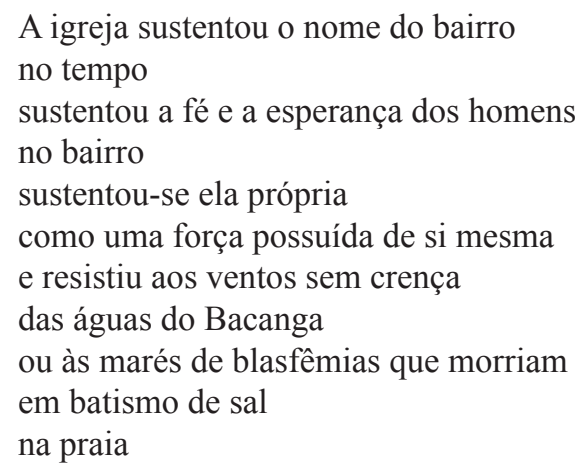

(CHAGAS, 2002, p. 219)

A Igreja Nossa Senhora do Desterro é elemento central na memória do Bairro, pois "sustentou a fé e a esperança dos homens...”. Representa o que é construído, destruído e reconstruído num processo dialético da dinâmica da vida e da existência. A igreja traz em si marcas de memórias. Como diz Santos (2015, p. 84), “Aquilo que está registrado em arranhões, fissuras e gretas de espaços percorridos, não carrega seu passado, mas sim, marcas de histórias e memórias dos habitantes do lugar. ”

Figura 2 - Igreja Nossa Senhora do Desterro

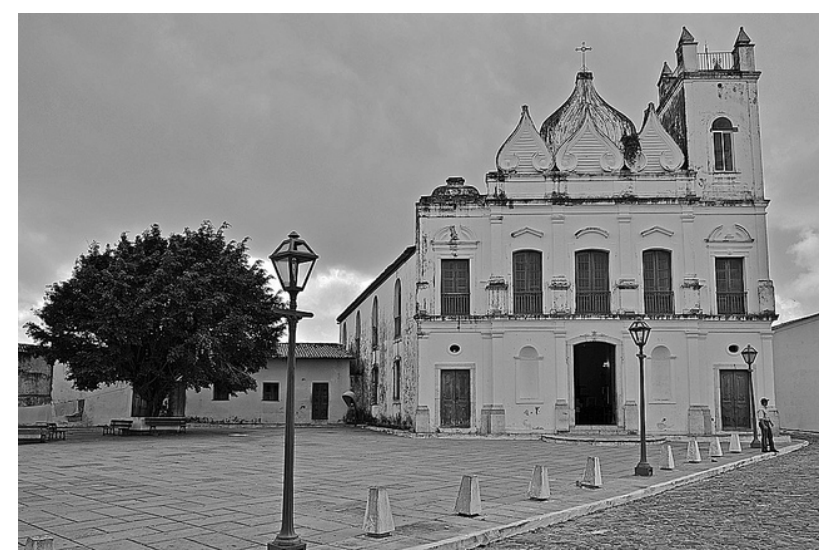

Fonte: https://passeiourbano.com/2012/11/04/igreja-de-sao-jose-do-desterro/ 
A passagem do homem pelo bairro é transitória, mas deixa marcas que resistem à inconstância do tempo, registrando-se em sua paisagem: calçadas, ruas, paredes, casarões, mirantes. As ruas, por exemplo, conservam memórias que se diluíram no tempo, escorrendo nas pedras, conforme diz o sujeito poético: "mas as ruas também diluem o homem/ na paisagem ocupada de lembranças/ que se espelham no polir das pedras" (CHAGAS, 2002, p. 207). Os logradouros têm nomes que carregam histórias: a Rua do Giz, a título de exemplo, é oficialmente registrada como "Rua 28 de Julho", referindo-se à data em que o Maranhão aderiu à Independência do Brasil no ano de 1923. Já "O Beco da Bosta" recebeu esse nome porque era o lugar por onde passavam os escravos com os tonéis de excrementos dos seus senhores para serem despejados ao mar.

O Desterro é mais do que uma demarcação geográfica, é uma rede de memórias construídas por seus habitantes. Constitui-se de lembranças e esquecimentos, de vozes e silenciamentos, de palavras, ausências, ações e omissões: "o bairro vive/cada ladeira/ cada declive/ cada canseira/ o bairro escuta/ a queixa igual/ da prostituta/ do marginal/ o bairro exprime/ a sua sorte/ em cada crime/ em cada morte" (CHAGAS, 2002, p. 244).

O Desterro é imortalizado em Os canhões do silêncio em virtude do seu inestimável valor histórico, cultural e social. Desse modo, ele se desmaterializa fisicamente e se reconstrói poeticamente, num processo em que objeto e palavra se comunicam, interagem e se fazem poesia.

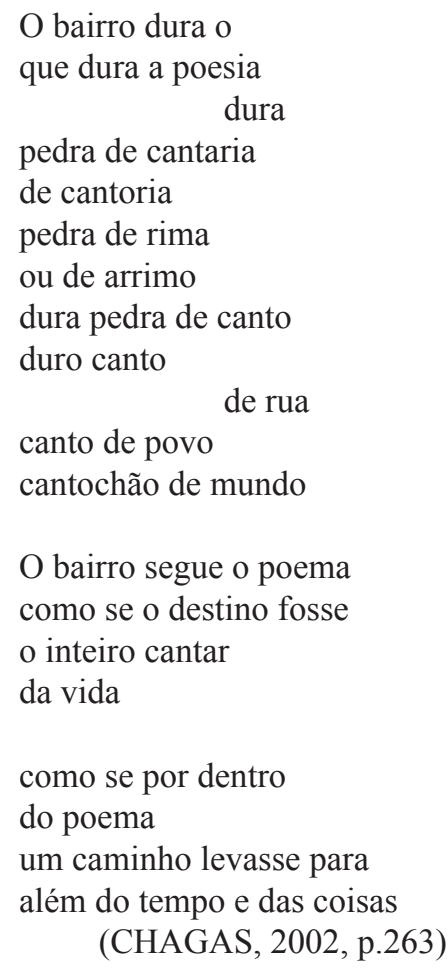

O sujeito poético diz que "o bairro dura o/ que dura a poesia", a poesia transcende tempo e espaço, então o bairro e seus elementos também os transcendem, imortalizando-se no poema. O jogo linguístico entre os componentes do poema e do bairro se relacionam de tal modo, que a "pedra de cantaria e cantoria" são ressignificadas. Dessa forma, a palavra "cantaria"1 remete à memória do lugar encrustada nas pedras fundadoras dos casarões e "cantoria" à poética construída a partir dessa memória. Assim, o bairro é todo poesia, e esta o reconstrói em um processo dialético que o eterniza.

1 A pedra de cantaria era feita de rochas talhadas em formas geométricas, vindas de Portugal, que serviam para pavimentação das ruas, calçamentos e construções dos casarões coloniais. 


\section{Considerações finais}

Em Os canhões do silêncio, o mirante constitui-se o lugar do dizer poético. Nele e a partir dele, o sujeito rememora e dá vasão aos sonhos e à imaginação, sendo ressignificadas as lembranças particulares e sociais.

O tempo que predomina na obra não é o cronológico, o eu poemático quebra "a louça do tempo" objetivo e cria a temporalidade subjetiva, onde a existência flui mais lentamente. O eu lírico voltase para a intimidade: repouso e recolhimento, confundindo-se com o espaço, cuja unidade o faz anunciar: "Eu sou o mirante", gerando a tríade sujeito - tempo - espaço.

No mirante, as marcas temporais reluzem nos azulejos, nas paredes de pedra e cal, nos telhados, fundindo-se com outros espaços da cidade, comunicando o passado, ao tempo em que o atualiza, construindo sentidos do ontem-agora que são percebidos pelo sujeito poético, o qual ressignifica movências no "tempoema".

A cidade é rebobinada como uma linha, sendo, de forma metonímica, representada pelo Bairro do Desterro. Sob o campo de visão sensível do eu lírico, o Bairro encrava-se no corpo poemático e se transforma em espaço de memória. A transmutação da matéria em memória poética é uma espécie de reserva, face à fragmentação e extinção dos elementos e espaços urbanos, resultante da ação do tempo objetivo.

Desse modo, o sujeito poético constrói sua percepção sobre a cidade, movendo-se no tempo que comunica por meio de fissuras, cal e pedra. Assim a urbe antiga dialoga com a moderna, num processo de hibridização espaço-temporal. Antigo e moderno, o velho e o novo convivem numa relação de interdependência e continuidade. Nesse movimento, o espaço urbano se reconstrói como símbolo do ontem e do hoje, produzindo sentidos e sensações em um processo dialético ininterrupto.

\section{Referências}

BACHELARD, Gaston. A poética do devaneio. Tradução de Antônio de Pádua Danesi. São Paulo: Martins Fontes, 1988.

BACHELARD, Gaston. A poética do espaço. São Paulo: Martins Fontes, 2008.

BERGSON, Henri. Matéria e memória: ensaio sobre a relação do corpo com o espírito. 2. ed. São Paulo: Martins Fontes, 1999.

BENJAMIN, Walter. Magia e técnica, arte e política: ensaios sobre literatura e história da cultura. Tradução de Sergio Paulo Rouanet. São Paulo: Editora Brasiliense, 1987.

CHAGAS, José. Os canhões do silêncio. 3 ed. São Paulo: Editora Siciliano, 2002.

DOBAL, H. A cidade substituída. In: Poesia reunida. 2. Ed. Teresina: Oficina da Palavra, 2005.

HEIDEGGER, Martin. A caminho da linguagem. Tradução de Márcia Sá Cavalcante Schuback. Rio de Janeiro: Vozes, Bragança Paulista; São Paulo: Editora Universitária de São Francisco, 2003.

SANTOS, Silvana Maria Pantoja dos. Literatura e memória entre os labirintos da cidade: representações na poética de Ferreira Gullar e H. Dobal. São Luís: Editora da UEMA, 2015. 
